\title{
New evidence for the age of the Athol Formation (Middle Jurassic; Bajocian) in the Tusk-1 and Tusk-2 wells, offshore Carnarvon Basin Western Australia
}

\author{
JAMES B. RIDING, GERD E. G. WESTERMANN AND D. P. FIONA \\ DARBYSHIRE
}

Riding, J.B., WeStermanN, G.E.G. \& DARBYSHIRE, D.P.F. 200X. New evidence for the age of the Athol Formation (Middle Jurassic; Bajocian) in the Tusk-1 and Tusk-2 wells, offshore Carnarvon Basin Western Australia. Alcheringa XX, yyy-zzz. ISSN 0311-5518.

The co-occurrence of ammonites with palynomorphs in the Athol Formation of the Tusk-1 and Tusk-2 wells drilled in the offshore Carnarvon Basin, Western Australia confirms the Early Bajocian (Middle Jurassic) age of the Dissiliodinium caddaense dinoflagellate cyst Oppel Zone. The macrofaunas refine this Early Bajocian age to the early Laeviuscula Chronozone. A belemnite from the Tusk-1 well has a strontium isotope $\left({ }^{87} \mathrm{Sr} /{ }^{86} \mathrm{Sr}\right)$ ratio which is consistent with the biostratigraphical age. All the identifiable ammonites belong to Pseudotoites robiginosus (Crick). Pseudotoites is prominent in the Early Bajocian of the Indo-Pacific Realm, being known mainly from onshore Western Australia and the Southern Andes, together with rare occurrences in Irian Jaya (west New Guinea); somewhat surprisingly, it is also rarely present in southern Alaska. The palynofloras studied from the Tusk-1 and Tusk-2 wells contain abundant specimens of the marine dinoflagellate cyst Dissiliodinium caddaense, and are assigned to the Dissiliodinium caddaense Oppel Zone. The Athol Formation is a correlative of the Newmarracarra Limestone of onshore Western Australia; the distribution of both these units indicates a marine transgression onto the Australian block during the Early Bajocian.

James B. Riding [jbri@bgs.ac.uk], Kingsley Dunham Centre, British Geological Survey, Keyworth, Nottingham NG12 5GG, UK; Gerd E. G. Westermann [gwestermann@sympatico.ca], Professor Emeritus, School of Geography and Geology, McMaster University, Hamilton, Canada L8S 4M1; D. P. Fiona Darbyshire [dpfd@nigl.nerc.ac.uk], NERC Isotope Geosciences Laboratory, Keyworth, Nottingham NG12 5GG, UK

Key words: ammonites, palynomorphs, strontium isotope stratigraphy, Middle Jurassic, Bajocian, Laeviuscula Chronozone, Western Australia, taxonomy, biostratigraphy.

THE TUSK-1 AND TUSK-2 WELLS were drilled in the offshore Carnarvon Basin, Western Australia (Fig. 1), and both cored the Athol Formation. The wells were drilled by Apache Northwest Pty Ltd, and the geographical coordinates are $20^{\circ} 14^{\prime}$ $44^{\prime \prime} ; 116^{\circ} 08^{\prime} 08^{\prime \prime}$ ' and 20 14 ' 16"; $116^{\circ} 08^{\prime} 18^{\prime \prime}$ respectively (Fig. 1). Ammonites are key tools for correlation of marine successions between continents. However, ammonite specimens are rarely encountered from offshore wells in the Indian and Pacific oceans. Here we report ammonites and palynomorph assemblages from eight 
samples of the Athol Formation between $1206.60 \mathrm{~m}$ and $1165.16 \mathrm{~m}$ in Tusk-1, and two samples between $1194.45 \mathrm{~m}$ and $1193.41 \mathrm{~m}$ in Tusk-2 (Table 1). These biotas are indicative of an Early Bajocian (Middle Jurassic) age. This age has been corroborated using strontium isotope stratigraphy on a sample at 1171.90-1171.80 $\mathrm{m}$ in the Tusk-1 well. The ammonites allow the refinement of this age assessment to the early Laeviuscula Chronozone.

\section{Ammonites}

The genus Pseudotoites. For the bibliographical references pertaining to the other ammonite taxa mentioned, see Westermann (1969) and Westermann \& Riccardi (1979).

Geographical and stratigraphical distribution.

Westermann \& Riccardi (1979, p. 136) gave a comprehensive discussion of Pseudotoites. The geographical distribution of this genus is exclusively Indo-circumPacific (Arkell in Arkell \& Playford 1954, Westermann 1964, 1969). The stratigraphical range of Pseudotoites approximates to the Early Bajocian Laeviuscula Chronozone (Fig. 2). The nature of the Pseudotoites faunas in Western Australia, Irian Jaya (west New Guinea), the Southern Andes and southern Alaska is described below.

Western Australia. The ammonite fauna of the Newmarracarra Limestone in the type area around Geraldton (northern Perth Basin) was monographed by Arkell in Arkell \& Playford (1954). This thin (11.4-3.3 m) unit contains endemic ammonite species and abundant shallow-water bivalves. Of the ammonite genera, Newmarracarroceras (formerly included in Fontannesia) and Pseudotoites are dominant, whereas the quasicosmopolitan Euhoploceras and Witchellia are rare. This Early Bajocian fauna was assigned to the "Sowerbyi Zone" (= the Discites and Laeviuscula chronozones) by Arkell in Arkell \& Playford (1954), Arkell (1956) and Westermann \& Riccardi (1979). However, Westermann \& Wang (1988) refined this correlation to the Laeviuscula Chronozone, including the Ovalis Subchronozone (Fig. 2).

The variable level of preservation of most ammonites in the Newmarracarra Limestone makes the differentiation of species of Pseudotoites extremely difficult. Most specimens are partially crushed, with only either the outer or the inner whorls preserved. Furthermore, Arkell in Arkell \& Playford (1954) was written at a time of taxonomic splitting, with several species based on only single, imperfect specimens that are now thought to represent extreme variants. The work of Arkell in Arkell \& Playford (1954) was revised by Westermann (1964), who significantly reduced the number of species and recognized sexual dimorphism. This simplified taxonomy was based on study of the plastotypes, and has largely stood the test of time.

Three ammonite morphogroups are distinguished from the Newmarracarra Limestone and these are listed below. The first two contain both macroconch and microconch allotypes. The valid species are listed below with subspecies or synonyms, numbers of specimens examined $(\mathrm{N})$, and diagnostic features. It is probable that these three morphogroups each consist of a single dimorphic species, however more stratigraphical research is needed to solve this taxonomic problem.

1. Platycones and sub-platycones from the upper part of the Newmarracarra Limestone

Macroconchs ( $q / \mathrm{M})$ : 
Ammonites (Perisphinctes) championensis Crick, $1894(\mathrm{~N}=4)$. The fine secondaries disappear on the body-chamber.

Pseudotoites brunnschweileri Arkell, $1954(\mathrm{~N}=3)$. The secondaries are dense, and the diameter is small.

Pseudotoites fasciculatus Arkell, $1954(\mathrm{~N}=3-4)$. The secondaries are dense and prominent.

Stephanoceras leicharti Neumayr, 1885 (type species; $\mathrm{N}=6-12$ ). The maximum diameter is $>140 \mathrm{~mm}$.

Microconchs $(\widehat{\jmath} / \mathrm{m})$ (= subgenus Latotoites Westermann, 1964; type species Ammonites australis Crick, 1894):

Ammonites (Stephanoceras) australis Crick, $1894(\mathrm{~N}=>2-3)$. The maximum diameter is $85-90 \mathrm{~mm}$.

Ammonites (Sphaeroceras) semiornatus Crick, $1894(\mathrm{~N}=>18)$. The maximum diameter is $75 \mathrm{~mm}$.

Pseudotoites spitiformis Arkell, $1954(\mathrm{~N}=1-2)$. The maximum diameter is 81 $\mathrm{mm}$; stouter, more prominent tubercles and rursiradiate secondaries are present.

Note that Ammonites semiornatus and Pseudotoites spitiformis were previously considered to be dwarf macroconchs (Arkell 1954, Westermann 1964, Westermann \& Riccardi 1979). However, they are smaller than the largest Ammonites australis, an unequivocal microconch (Arkell, 1954, pl. 31, fig. 2). Ammonites semiornatus is the best known form because of its abundance and good preservation.

2. Sub-sphaerocones from the middle part of Newmarracarra Limestone

Macroconchs ( $+/ \mathrm{M})$ :

Ammonites (Perisphinctes) robiginosus Crick, $1894(\mathrm{~N}=>20)$. The maximum diameter is $160 \mathrm{~mm}$.

Pseudotoites emiloides Arkell, $1954(\mathrm{~N}=12)$. The ribs and tubercles are sharp and dense.

Microconchs (ð/m):

Ammonites (Sphaeroceras) woodwardi Crick, $1894(\mathrm{~N}=>12)$.

Otoites antipodus Arkell, $1954(\mathrm{~N}=>5)$. Coarse ribs and tubercles are present.

3. Cadiconic "coronates"

Macroconchs ( $/ \mathrm{M})$ (microconchs and stratigraphical levels unknown):

Zemistephanus armatus Arkell, $1954(\mathrm{~N}=1)$. This specimen is extremely ornate.

Zemistephanus corona Arkell, $1954(\mathrm{~N}=2)$.

The stratigraphical distribution of the ammonites in the Newmarracarra Limestone demonstrates that the dimorphic pair Ammonites (Perisphinctes) robiginosus ( $(\mathrm{M} \mathrm{M})$ - Ammonites (Sphaeroceras) woodwardi ( $\lesssim / \mathrm{m})$ (morphogroup 2) 
occurs mainly in the middle part of the unit (Playford in Arkell \& Playford 1954, fig. 2). Also, that the pair Stephanoceras leicharti ( $9 / \mathrm{M})$ - Ammonites (Sphaeroceras) semiornatus $(\widehat{\delta} / \mathrm{m})$ (morphogroup 1$)$ is confined to the upper part of the Newmarracarra Limestone (Playford in Arkell \& Playford 1954, fig. 2). The stratigraphical position of the rare "extreme coronates" is unknown.

The age of Pseudotoites species is based on other occurrences, mainly in South America (see below), and on associated ammonites. The affinities and age of the abundant Fontannesia clarkei Crick (including Fontannesia whitehousei Arkell), and of the rare Fontannesia fairbridgei Arkell were reviewed by Hall (1989). Hall (1989) placed both species in his new, endemic genus Newmarracarroceras, which is closely related to the mainly European genus Fontannesia. Newmarracarroceras clarkei appears at the base of the Newmarracarra Limestone. Most Pseudotoites range up to the middle of the Pseudotoites gr. leicharti-semiornatus range zone (Playford 1990). The age of the true Fontannesia is best known from Europe, where this genus ranges from the uppermost Aalenian to the Lower Bajocian (Laeviuscula Standard Zone; Ovalis Standard Subzone) (Cariou \& Hantzpergue 1997). Hall (1989) noted the close affinity between some southern European forms and the endemic Western Australian forms. The endemic Euhoploceras playfordi Arkell also occurs throughout most of the range of Pseudotoites. In Europe, the range of Euhoploceras is the Concavum and Discites Standard Zones (Aalenian-Bajocian). According to Hall (1989), however, the closest affinity is to the long-ranging Euhoploceras amosi Westermann \& Riccardi from the Malarguensis-Singularis Standard Zones of westcentral Argentina. This interval is equivalent to the upper Concavum-lower Laeviuscula Standard Zones (Ovalis Standard Subzone) of Europe. Witchellia australica Arkell, known only in a few specimens from the middle part of the formation (Playford in Arkell and Playford 1954), mitigates against a correlation with the Laeviuscula Standard Zone. A similar Fontannesia sp. cf. F. clarkei-Witchellia association is also present in the Laeviuscula Standard Zone of southern Tibet (Playford in Arkell \& Playford 1954, Westermann \& Wang 1988). This supports the dating of the Western Australian Pseudotoites fauna as mainly early Laeviuscula Standard Zone by Hall (1989).

Irian Jaya (west New Guinea). Pseudotoites cf. robiginosus (Crick) $9 / \mathrm{M}$ (= Stephanoceras cf. humphriesianum forma indica of Kruizinga 1926) and Pseudotoites cf. woodwardi (Crick) (= Visser \& Hermes 1962, figs. 17, 18; fide Westermann \& Getty 1970 , table 1) are only known from ex situ collections, and therefore cannot be dated.

Southern Andes. The rich and extensively monographed Pseudotoites fauna of westcentral Argentina ranges through the Singularis and lower Giebeli Standard Zones, Submicrostoma Standard Subzone (Westermann \& Riccardi 1979, p. 113, table 2; Westermann in Hillebrandt et al. 1992, table 12.2). This interval includes abundant representatives of Pseudotoites spp., with Pseudotoites singularis (Gottsche) most abundant in the lowermost part, and Pseudotoites sphaeroceroides (Tornquist) in the uppermost part. The Singularis Standard Zone also yields abundant Euhoploceras (Fissilobiceras) spp., including the rare European index Euhoploceras ovalis (Quenstedt), latest Euhoploceras (Euhoploceras), early Sonninia (Papilliceras) and rare Sonninia alsatica (Haug). This fauna indicates a tentative correlation with the uppermost Discites Standard Zone and the Ovalis Standard Subzone of the Laeviuscula Standard Zone. The lower Giebeli Standard Zone, Microstoma Standard 
Subzone, yields early representatives of Emileia, together with Sonninia (Papilliceras). It is correlated with the upper Laeviuscula Standard Zone, approximately equivalent to the Trigonalis and Laeviuscula Standard Subzones (Cariou \& Hantzpergue 1997, p. 43). This conclusion was reached mainly by stratigraphical interpolation. The upper Giebeli Standard Zone, Multiformis Standard Subzone, contains Emileia (Emileia) sp. aff. E. brochii (Sowerby), Emileia (Emileia) sp. cf. E. vagabunda Buckman and Stephanoceras (Skirroceras) spp. This is typical of the European Propinquans Standard Zone (= "Sauzei Standard Zone"). The Pseudotoites range zone, therefore, is approximately coeval with the Laeviuscula Standard Zone (sensu lato).

South Alaska. Rare endemic Pseudotoites occur in the upper Widebayense Standard Zone, Sutneroides Standard Subzone, of the Alaskan Peninsula (Hall \& Westermann 1980). These are Pseudotoites kialagvikensis Westermann \& Riccardi and Pseudotoites prestoni Westermann. They are accompanied by the abundant endemic species Docidoceras (Pseudocidoceras) widebayense Westermann and Witchellia sutneroides Westermann. The former, abundant species, was originally assigned to Pseudotoites by Arkell (1954, 1956), whereas unequivocal Pseudotoites were identified in more recent collections from Wide Bay (Westermann 1969). This assemblage is superjacent to the Camachoi Standard Subzone, with Docidoceras (Pseudocidoceras) camachoi Westermann and Euhoploceras biifurcata Westermann, and was correlated with the Discites Chronozone by Hall \& Westermann (1980). The Sutneroides Assemblage Zone is therefore dated as early Laeviuscula Chronozone, Ovalis Chronosubzone. Arkell $(1954,1956)$ also misidentified "Ammonites” carlottensis Whiteaves and Zemistephanus McLearn from the Cook Inlet region of southern Alaska and the Queen Charlotte Islands of British Columbia as representatives of the Western Australian Pseudotoites fauna. The endemic northeast Pacific stephanoceratid genus Zemistephanus is present in the Kirschneri Standard Zone (Westermann 1964, Hall \& Westermann 1980).

The ammonite faunas from the Athol Formation of Tusk-1 and Tusk-2 wells Specimens of the ammonite genus Pseudotoites Spath, 1929 were recovered from six samples of the Athol Formation between $1205.60 \mathrm{~m}$ and $1165.16 \mathrm{~m}$ in Tusk-1, and between $1194.45 \mathrm{~m}$ and $1193.41 \mathrm{~m}$ in Tusk-2 (Table 1). The macroconchs $(\mathrm{q} / \mathrm{M})$ recovered are large representatives of the Family Otoitidae Mascke, 1907 with prominent bullae or spines on the outer whorls. The inner whorls are almost platyconic with fine, often blunt and prorsiradiate primaries, usually becoming depressed at 30-40 mm diameter with cadiconic intermediate whorls. The bodychamber is rounded.

All the figured ammonites in Figs. 3-5 are housed in the Commonwealth Palaeontological Collection (CPC) of Geoscience Australia (GA), Canberra, ACT 2601, Australia.

Family Otoitidae Mascke, 1907

Pseudotoites Spath, 1929

Type species: Stephanoceras leicharti Neumayr, 1885.

Pseudotoites robiginosus (Crick, 1894) $9 / \mathrm{M}($ Figs 3A-B, 4) 
1894 Ammonites (Perisphinctes) robiginosus Crick, p. 483, pl. 12, figs 3a, b.

1954 Pseudotoites robiginosus (Spath) Arkell, p. 547, pl. 34, figs. 1-4, pl. 35, figs 1, 2, pl. 37, figs 5, 6 (part).

1954 Pseudotoites emilioides Arkell, pl. 24, fig. 5, pl. 37, figs 3, 4.

Material. One adult macroconch from sample SC-21 (CPC 37056), internal mould, outer 1.25 whorls with half-whorl body-chamber, last three-quarter whorls preserved with left flank only (venter cut off by the drillbit), previous half-whorl partly crushed laterally. One fragment of intermediate whorls from sample SC-28 (CPC 37058), internal mould, well-preserved left side and venter.

Description. Intermediate whorls between 40 and $76 \mathrm{~mm}$ diameter (SC-28 - CPC 37058), moderately evolute (umbilicus $=0.30$ diameter) and strongly depressed, twice as high as wide. The innermost flank (umbilical slope) is smooth. Rectiradiate primaries arise at mid-flank, are widely spaced (12 per half-whorl) and are moderately prominent. They end in small, somewhat bullate (longitudinally extended) tubercles on subangular lateral edge at about $2 / 5$ the whorl height. Secondaries arise in threes or as single intercalatories; the cross is straight over the venter to about $60 \mathrm{~mm}$ diameter then it begins to project, forming a shallow arch.

The outer whorl, between approximately $80 \mathrm{~mm}$ and the reconstructed diameter of $140 \mathrm{~mm}$ at aperture (SC-21), is poorly known. The umbilical slope of the lower flank is steep to subvertical at the proximal end of the body-chamber. This whorl is more coarsely sculptured than the intermediate whorls of SC-28, with about 10 primaries per half-whorl that divide into more prominent bullate tubercles and into three secondaries, without intercalatories. The body-chamber egresses at first gradually, then abruptly, towards the aperture, with flattening of the inner flank and umbilical slope. The primaries combine with the tubercles to form extremely coarse bullae on the inner flank; the secondaries are unknown.

Discussion. The intermediate whorls of SC-28 are much more finely ornamented than the outer whorl of SC-21, even at similar diameters $(76-80 \mathrm{~mm})$. Specimen SC28 closely resembles var./subsp. emilioides, and specimen SC-21 is closer to the more coarsely-ribbed typical P. robiginosus sensu stricto.

The var./ssp. emilioides macroconch closely resembles Pseudotoites sphaeroceroides (Tornquist) from the Andes (cf. Westermann \& Riccardi 1979, pl. 11, 12). It differs mainly in its more numerous secondaries and more distant primaries. Significantly, the Andean microconch resembles the Australian microconchs "Ammonites (Sphaeroceras)" woodwardi Crick and "Otoites" antipodus Arkell (see above and Arkell 1954, pl. 30).

Pseudotoites sp. indet. +/M (Figs 3C-E, 5A-B)

Material. One macroconch from SC-35 (CPC 37063), and one septate whorl from SC-20 (CPC 37055); both are badly crushed and incomplete internal moulds that cannot be identified to species level.

Discussion. SC-35 (CPC 37063) is an adult macroconch with remnants of the aperture at a reconstructed diameter of $130 \mathrm{~mm}$. Only the right side of last third whorl of the body-chamber is preserved, it is ornamented only by distant, blunt tubercles. 
The end of the penultimate whorl has similar ornamentation and remnants of dense, faint secondaries. The intermediate whorls at ca 35-60 $\mathrm{mm}$ diameter have only about 10 prominent, probably prorsiradiate (unless caused by compaction) primaries that arise near the middle of the inner flank, and rapidly develop bullate tubercles. The secondaries are dense and probably straight. Small parts of the innermost whorls are exposed in the umbilicus; they have smooth inner flanks, and oblique bullae on the lateral edges.

Sample SC-20 (CPC 37055) is a septate intermediate whorl of $85 \mathrm{~mm}$ diameter, crushed so that the inner whorls have become acutely lenticular. The rectiradiate ornamentation consists of distant (ca 10 per half-whorl), short and blunt primaries that form prominent bullae on the rounded lateral shoulder. It has four times as many, blunt dense secondaries; this is visible even on fragments of shell. This specimen resembles SC-35.

\section{Palynology}

The palynology of nine samples from the Athol Formation of the Tusk-1 and Tusk-2 wells was studied in order to place the assemblages biostratigraphically (Table 1). The seven samples from Tusk- 1 and the two samples from Tusk- 2 produced abundant and well-preserved palynofloras. All palynomorph taxa mentioned at species level are listed, with their respective author citations, in Appendix 1. The residues comprise common/abundant wood and other plant tissues, but amorphous organic material is largely absent.

The palynofloras include dinoflagellate cysts (mainly Dissiliodinium caddaense), gymnosperm pollen (dominantly Callialasporites spp.), and pteridophytic spores (largely Cyathidites spp.; Tables 2-4). The presence of abundant marine microplankton throughout indicates a consistent open-marine depositional setting. Likewise, the constant occurrence of abundant Dissiliodinium caddaense indicates that the samples are all within the Dissiliodinium caddaense Oppel Zone of Helby et al. (1987). This species is extremely abundant, for example 762 and 653 specimens per microscope slide were counted in samples SC-22 and SC-31 respectively (Table 2). Dissiliodinium caddaense is confined to this biozone, and its abundant presence characterises the middle part of the interval (Helby et al., 1987, fig. 15). The Dissiliodinium caddaense Oppel Zone is of Early to "middle" Bajocian age according to Helby et al. (1987, fig. 46). The age of this zone was interpreted as Early Bajocian (Laeviuscula Chronozone), on the basis of the coeval ammonite faunas of the Newmarracarra Limestone of onshore Western Australia (e.g. Hall, 1989). This study confirms that interpretation. The other dinoflagellate cysts such as Nannoceratopsis deflandrei and Pareodinia halosa are entirely consistent with an Early Bajocian age (Helby et al. 1987). The pollen-spore floras are especially rich in Callialasporites dampieri and Callialasporites turbatus (Tables 3, 4). This favours a correlation to the Callialasporites turbatus Oppel Zone of Helby et al. (1987) which is of Toarcian to Early Bajocian age.

\section{Strontium Isotope Stratigraphy}

Analytical details. Fragments of SC23, a belemnite specimen from 1171.90-1171.80 $\mathrm{m}$ (Table 1) were hand-picked under a binocular microscope, and pre-leached in double quartz distilled dilute hydrochloric acid. A subsample of $\sim 100$ milligrams was dissolved in ultrapure $1 \mathrm{M}$ acetic acid and the strontium was separated by conventional cation exchange techniques using Biorad AG 50W-X8 resin. Isotope ratios were 
initially measured on a Finnegan MAT 262, multicollector, mass spectrometer operated in dynamic mode with the strontium sample loaded on a tantalum filament treated with phosphoric acid. A replicate analysis was made on a Finnegan MAT Triton operated in static mode with the strontium sample loaded on a rhenium filament together with a tantalum oxide $(\mathrm{TaO})$ activator following the method of Birck (1986). Thirty analyses of the international strontium isotope standard NBS 987 measured on the MAT 262 during the period of study yielded a mean ${ }^{87} \mathrm{Sr} /{ }^{86} \mathrm{Sr}$ ratio of $0.710249 \pm 0.000014(2 \sigma)$. The relevant mean value obtained for the NBS 987 on the Triton was $0.7102533 \pm 0.0000070(2 \sigma n=17)$. For consistency, the ratios measured for SC23 are normalized relative to the accepted value of 0.710248 for NBS 987. Replicate determinations in this laboratory $(\mathrm{n}=172)$ of a north Atlantic seawater standard yield $0.7091752 \pm 0.0000098(2 \sigma)$.

A preleached subsample was also taken for major and trace element analysis. Shell fragments were leached in ultrapure $1 \mathrm{M}$ acetic acid for four hours. The leachate was evaporated to dryness, and the residue taken up in $1 \%$ nitric acid. Geochemical data were obtained by ICP-AES on a Fison/ARL 3580 simultaneous/sequential spectrometer with Gilson auto sampler. For stable isotope analysis, the equivalent of $10 \mathrm{mg}$ of carbonate was reacted with anhydrous phosphoric acid in vacuo overnight at a constant $25^{\circ} \mathrm{C}$. The $\mathrm{CO}_{2}$ liberated was separated from water vapour under vacuum and collected for analysis. Measurements were made on a VG Optima mass spectrometer. Overall analytical reproducibility for these samples is normally better than $0.1 \%$ for $\delta^{13} \mathrm{C}$ and $\delta^{18} \mathrm{O}(2 \sigma)$. Isotope values $\left(\delta^{13} \mathrm{C}, \delta^{18} \mathrm{O}\right)$ are reported as per mil (\%o) deviations of the isotopic ratios $\left({ }^{13} \mathrm{C} /{ }^{12} \mathrm{C},{ }^{18} \mathrm{O} /{ }^{16} \mathrm{O}\right)$ calculated to the VPDB scale using a within-run laboratory standard calibrated against NBS standards.

Results and interpretations. The palaeontological age of the succession studied in the Tusk-1 well is corroborated by strontium isotope stratigraphy. The $\mathrm{Sr}$ isotope signature of SC 23 , measured on two separate instruments, yielded ${ }^{87} \mathrm{Sr} /{ }^{86} \mathrm{Sr}$ ratios of 0.707249 and 0.7072496 , which are indistinguishable. They just overlap within the analytical error of the lowest ratio measured by McArthur et al. (2000) for belemnites from the lowermost Standard Subzone of the Bajocian Stage (i.e. the Walkeri Standard Subzone, Discites Standard Zone) at Bearreraig, Isle of Syke, Scotland. The ${ }^{87} \mathrm{Sr}{ }^{86} \mathrm{Sr}$ ratio of 0.7072496 indicates an Early Bajocian age on the LOWESS curve of McArthur \& Howarth (2004). Sample SC23 has low concentrations of Mn and Fe (1.9 $\mathrm{mg} / \mathrm{kg}$ and $9 \mathrm{mg} / \mathrm{kg}$ respectively) and relatively high amounts of $\mathrm{Mg}(4147 \mathrm{mg} / \mathrm{kg})$ and $\mathrm{Sr}(1373 \mathrm{mg} / \mathrm{kg})$, which suggest pristine shell calcite (McArthur, 1994 and references therein). The stable isotope data $\left(\delta^{13} \mathrm{C} 2.4 \%\right.$ and $\delta^{18} \mathrm{O}-0.7 \%$ ) are consistent with marine signatures, and suggest that the material has not equilibrated with meteoric water (Veizer et al., 1999), hence the Early Bajocian strontium isotope age is considered to be reliable.

\section{Conclusions}

The Athol Formation in the Tusk- 1 and Tusk- 2 wells, Western Australia, has yielded ammonites and palynomorphs that indicate an Early Bajocian age. This age assessment was corroborated using strontium isotope stratigraphy. The ammonites, which are all referable to the typically Indo-circum-Pacific genus Pseudotoites, allow the refinement of this determination to the early Laeviuscula Chronozone.

The palynomorph assemblages contain abundant specimens of the marine dinoflagellate cyst Dissiliodinium caddaense, and hence they are assigned to the Dissiliodinium caddaense Oppel Zone of Helby et al. (1987), which is of Early 
Bajocian age. This report confirms the dating of the Dissiliodinium caddaense Oppel Zone and provides a valuable chronostratigraphic tie-point for the Western Australian Jurassic succession. Helby et al. (1987, p. 25) stated that this zone is of Bajocian age based on the work of Filatoff (1975, p. 7). Basically, Helby et al. (1987) used the dinoflagellate cyst content of the Cadda Formation and its lower and upper transitions as described by Filatoff (1975) to define their Dissiliodinium caddaense Oppel Zone. This age determination is based on the Cadda Formation being partially coeval with the Newmarracarra Limestone (Filatoff, 1975, fig. 2), which is of unequivocal Early Bajocian age. The present study conclusively proves that representatives of Pseudotoites, which correlate to the early Laeviuscula Chronozone co-occur with dinoflagellate cysts indicative of the Dissiliodinium caddaense Oppel Zone.

Furthermore, it is clear that the Athol Formation is a correlative of the Newmarracarra Limestone of the onshore Perth Basin, Western Australia. The presence of extensive, well-developed Early Bajocian marine macrofaunas and palynomorphs in several Western Australian basins indicates an Early Bajocian phase of marine transgression onto the Australian block. This is consistent with a global transgressive trend at this time (Haq et al. 1987), and the stratigraphically isolated nature of marine dinoflagellate cysts in the Early to "middle" Bajocian Dissiliodinium caddaense Oppel Zone of Helby et al. (1987, figs. 15, 46).

\section{Acknowledgements}

This contribution is part of a joint British Geological Survey (BGS) and Geoscience Australia (GA) joint research initiative under the auspices of the Virtual Centre of Economic Micropalaeontology and Palynology (VCEMP). The authors are grateful to Clinton B. Foster (GA, Canberra) for promoting and facilitating this research. The manuscript was thoroughly and perceptively reviewed by Tony Allen, Steve McLoughlin, Kevin N. Page and Phillip E. Playford. James B. Riding publishes with the permission of the Executive Director, British Geological Survey (NERC). All three authors publish with the approval of the Chief Executive Officer, Geoscience Australia.

\section{References}

ARKELL, W.J., 1954. Part II. The ammonites and their place in the Bajocian faunas of the world. In W.J. ARKELl \& P.E. PLAYFORD 1954, 557-597 (see below).

ARKELl, W.J., 1956. Jurassic Geology of the World. Oliver \& Boyd, Edinburgh, xv + $806 \mathrm{p}$

ARKell, W.J. \& Playford, P.E., 1954. The Bajocian ammonites of Western Australia. Philosophical Transactions of the Royal Society of London, Series B 237, 547-604.

BIRCK, J.L., 1986. Precision K-Rb-Sr isotopic analysis: application to $\mathrm{Rb}-\mathrm{Sr}$ chronology. Chemical Geology 56, 73-83.

CARIou, E. \& HANTZPergue, P., 1997. Biostratigraphie du Jurassique OuestEuropéen et Mediterranéen. Bulletin des Centres de Recherches ExplorationProduction Elf-Aquitaine, Memoire 17. 
Fensome, R.A. \& Williams, G.L., 2004. The Lentin and Williams index of fossil dinoflagellates 2004 edition. American Association of Stratigraphic Palynologists, Contributions Series 42, 909 p

FiLAtoff, J., 1975. Jurassic palynology of the Perth Basin, Western Australia. Palaeontographica 154B, 1-120.

HALL, R.L., 1989. Lower Bajocian ammonites (Middle Jurassic; Sonniniidae) from the Newmarracarra Limestone, Western Australia. Alcheringa 13, 1-20.

HALl, R.L. \& WestermanN, G.E.G., 1980. Lower Bajocian (Jurassic) cephalopod faunas from western Canada and proposed assemblage zones for the Lower Bajocian of North America. Palaeontographica Americana 9(52), 5-93.

HAQ, B.U., HARDENBOL, J., \& VAIL, P.R., 1987. Chronology of fluctuating sea levels since the Triassic. Science 235, 1156-1169.

Helby, R., Morgan, R. \& PArtridge, A. D., 1987. A palynological zonation of the Australian Mesozoic. Association of Australasian Palaeontologists Memoir 4, 1-94.

Hillebrandt, A. V., Smith, P. Westermann, G.E.G. \& Callomon, J.H., 1992. Ammonite zones of the circum-Pacific region. The Jurassic of the Circum-Pacific, In G.E.G. Westermann, Cambridge University Press, New York, 247-272.

KruizingA, P., 1926. Ammonieten en eenige andere Fossielen uit de Jurassische Afzittingen de Soela Eilanden. Jaarboek Mijnwezen in Nederland Oostindies 4, 1185 .

McArthur, J.M., 1994. Recent trends in Sr isotope stratigraphy. Terra Nova 6, 331 358.

McArthUR, J.M. \& HowARTH, R.J., 2004. 7. Strontium isotope statigraphy. In F.M. Gradstein, J.G. OgG \& A.G. Smith, eds., A Geologic Timescale 2004. Cambridge University Press, Cambridge, 96-105.

McArthur, J.M., Morton, N. \& Thirlwall, M.F., 2000. Strontium isotope stratigraphy of the Aalenian/Bajocian auxiliary stratotype point at Bearreraig, Isle of Skye, NW Scotland. GeoResearch Forum 6, 137-144.

PlayFORD, P.E., 1990. Middle Jurassic (Bajocian) ammonites from the Newmarracarra Limestone, Western Australia. Alcheringa 14, 310.

Veizer, J., Ala, D., Azmy, K., Bruckschen, P., Buhl, D., Bruhn, F., Carden, G.A.F., Diener, A., Ebneth, S., Godderis, Y., Jasper, T., Korte, C., PAwellek, F., Podlaha, O.G. \& STRAuss, H. $1999 .{ }^{87} \mathrm{Sr} /{ }^{86} \mathrm{Sr}, \delta^{13} \mathrm{C}$ and $\delta^{18} \mathrm{O}$ evolution of Phanerozoic seawater. Chemical Geology 161, 59-88.

VISSER, W.A. \& HERMES, J.J., 1962. Geological results of the exploration for oil in Netherlands New Guinea. Koninklijk Nederlands Geologisch Mijnbouwkundig Genootschap Verhandelingen Geologische Series 20, 1-265. 
Westermann, G.E.G., 1964. Sexual-Dimoprhismus bei Ammonoideen und seine Bedeutung fur die Taxionomie der Otoitidae. Palaeontographica 124A, 33-73.

Westermann, G.E.G., 1969. The ammonite fauna of the Kialagvik Formation at Wide Bay, Alaska Peninsula. Part II. Sonninia sowerbyi Zone (Bajocian). Bulletin of American Paleontology 57 (225), 1-172.

Westermann, G.E.G. \& GetTy, T.A., 1970. New Middle Jurassic Ammonitina from New Guinea. Bulletin of American Paleontology 57 (256), 231-301.

WestermanN, G.E.G. \& RiCCARDI, A.C., 1979. Middle Jurassic ammonoid fauna and biochronology of the Argentine-Chilean Andes. Part II. Bajocian Stephanocerataceae. Palaeontographica 164A, 85-188.

Westermann, G.E.G., \& WANG, YI-GANG, 1988. Middle Jurassic ammonites of Tibet and the age of the lower Spiti Shales. Palaeontology 31, 295-339.

\section{APPENDIX 1: LIST OF PALYNOMORPH SPECIES}

This Appendix lists all valid, formally defined palynomorph taxa below generic level mentioned in this contribution with full author citations. Some additional taxa, not identified below generic level, are included in Tables 2-4. The palynomorphs are listed alphabetically within the four groups. References to the dinoflagellate cyst author citations are provided by Fensome \& Williams (2004).

Dinoflagellate cysts:

Dissiliodinium caddaense (Filatoff, 1975) Stover \& Helby, 1987

Nannoceratopsis deflandrei Evitt, 1961

Nannoceratopsis spiculata Stover, 1966

Pareodinia halosa (Filatoff, 1975) Prauss, 1989

Miscellaneous microplankton:

Botryococcus braunii Kützing, 1849

\section{Gymnosperm pollen:}

Araucariacites australis Cookson, 1947

Callialasporites dampieri (Balme, 1957) Sukh Dev, 1961

Callialasporites trilobatus (Balme, 1957) Sukh Dev, 1961

Callialasporites turbatus (Balme, 1957) Schulz, 1967

Classopollis classoides (Pflug, 1953) Pocock \& Jansonius, 1961

Microcachryidites antarcticus Cookson, 1947

Perinopollenites elatoides Couper, 1958

Vitreisporites pallidus (Reissinger, 1950) Nilsson, 1958

\section{Pteridophyte spores:}

Cibotiumspora juriensis (Balme, 1957) Filatoff, 1975

Concavissimisporites verrucosus Delcourt \& Sprumont, 1955

Cyathidites australis Couper, 1953 
Cyathidites minor Couper, 1953

Ischyosporites variegatus (Couper, 1958) Schulz, 1967

Osmundacidites wellmanii Couper, 1958

Sestrosporites pseudoalveolatus (Couper, 1958) Dettmann, 1963 
Fig. 1. The location of the Tusk-1 and Tusk-2 wells in the offshore Carnarvon Basin, Western Australia. The geographical coordinates are $20^{\circ} 14^{\prime} 44^{\prime}$ 'S $\mathrm{S} 116^{\circ} 08^{\prime} 08^{\prime}$ ' $\mathrm{E}$ (Tusk-1), and 20 $14^{\prime} 16^{\prime} ' \mathrm{~S} ; 116^{\circ} 08^{\prime} 18^{\prime}$ 'E (Tusk-2). The black circle in the inset map (bottom right) depicts the area shown in the main map, and the star symbol on the west coast of Western Australia indicates the outcrop area of the Newmarracarra Limestone.

Fig. 2. The correlation of the uppermost Aalenian and Lower Bajocian Standard Zones and Standard Subzones with associated biozones of Europe, the Andes and Alaska. The species names pertaining to the Standard Zones and Standard Subzones are written in Roman font with an initial capital letter. By contrast, species pertaining to the biozones are written in italic font with the species names starting with an initial lower case letter.

Fig. 3. A, B - Pseudotoites robiginosus (Crick) (Q/M) (CPC 37058). A fragment of the intermediate whorls from specimen SC-28. C-E - Pseudotoites sp. indet. ( $9 / \mathrm{M}$ ) (CPC 37055). A badly crushed septate whorl fragment from specimen SC-20. Scale bar $=1 \mathrm{~cm}$.

Fig. 4. Pseudotoites robiginosus (Crick) ( $(\mathrm{M} \mathrm{M})(\mathrm{CPC} 37056)$. The outer 1.25 whorls of an adult macroconch with 0.75 whorl representing the body-chamber. Note that the venter has been attenuated by the drill bit; this is specimen SC-21. Scale bar $=1 \mathrm{~cm}$.

Fig. 5. A, B - Pseudotoites sp. indet. ( $/$ /M) (CPC 27063). A crushed fragment of the outer whorls from specimen SC-35. Scale bar $=1 \mathrm{~cm}$. 


\begin{tabular}{|c|c|c|c|c|c|}
\hline $\begin{array}{c}\text { Well } \\
\text { number }\end{array}$ & $\begin{array}{l}\text { Sample } \\
\text { number }\end{array}$ & $\begin{array}{c}\text { CPC } \\
\text { number }\end{array}$ & Depth (m) & Ammonite name & Age \\
\hline Tusk-1 & SC 21 & 37056 & $1165.25-1165.16$ & $\begin{array}{c}\text { Pseudotoites robiginosus sensu } \\
\text { stricto } 9 / \mathrm{M}\end{array}$ & $\begin{array}{l}\text { Laeviuscula } \\
\text { Standard Zone }\end{array}$ \\
\hline Tusk-1 & $\mathrm{SC} 22$ & 37057 & $1170.81-1170.76$ & crushed ammonite aperture, indet. & $?$ \\
\hline Tusk-1 & SC 20 & 37055 & $1171.00-1170.90$ & Pseudotoites sp. indet. $+/ \mathrm{M}$ & $\begin{array}{l}\text { Laeviuscula } \\
\text { Standard Zone }\end{array}$ \\
\hline Tusk-1 & $\mathrm{SC} 23$ & $\mathrm{~N} / \mathrm{A}$ & $1171.90-1171.80$ & N/A & Early Bajocian \\
\hline Tusk-1 & $\mathrm{SC} 28$ & 37058 & $1182.04-1182.00$ & $\begin{array}{l}\text { Pseudotoites robiginosus } \\
\text { var./subsp. emiloides } \uparrow / \mathrm{M}\end{array}$ & $\begin{array}{l}\text { Laeviuscula } \\
\text { Standard Zone }\end{array}$ \\
\hline Tusk-1 & SC 31 & 37059 & $1205.60-1205.58$ & $\begin{array}{l}\text { crushed ammonite impression, } \\
\text { ?Pseudotoites }\end{array}$ & $\begin{array}{l}\text { ?Laeviuscula } \\
\text { Standard Zone }\end{array}$ \\
\hline Tusk-1 & SC 32 & 37060 & $1206.06-1206.04$ & $\begin{array}{c}\text { Indeterminate possible ammonite } \\
\text { aperture }\end{array}$ & $?$ \\
\hline Tusk-1 & SC 33 & 37061 & $1206.60-1206.50$ & Limidae bivalve, indet. & indeterminate \\
\hline Tusk-2 & SC 35 & 37063 & $1194.00-1193.90$ & Pseudotoites sp. indet. $+/ \mathrm{M}$ & $\begin{array}{l}\text { Laeviuscula } \\
\text { Standard Zone }\end{array}$ \\
\hline Tusk-2 & SC 34 & 37062 & $1194.45-1193.41$ & $\begin{array}{l}\text { crushed ammonite fragment, } \\
\text { ?Pseudotoites }\end{array}$ & $\begin{array}{l}\text { ?Laeviuscula } \\
\text { Standard Zone }\end{array}$ \\
\hline
\end{tabular}

Table 1. A listing of the ten samples from the Tusk-1 and Tusk-2 wells examined in this study, in ascending stratigraphic order. The strontium isotope stratigraphy of sample SC 23 (a belemnite) was studied. The remaining nine samples were studied for macrofossils and palynomorphs. The macrofossil identifications are summarized; note that all the identifiable ammonites belong to Pseudotoites, and are of the same age. 


\begin{tabular}{|c|c|c|c|c|c|c|c|c|c|c|}
\hline \multirow[b]{2}{*}{ 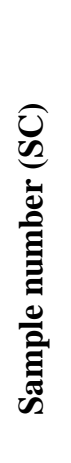 } & \multicolumn{7}{|c|}{ Dinoflagellate cysts } & \multicolumn{3}{|c|}{ Microplankton } \\
\hline & 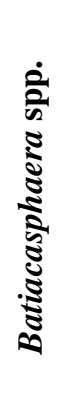 & 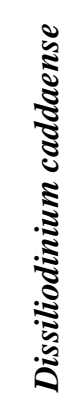 & 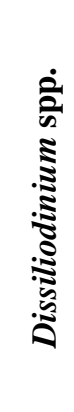 & 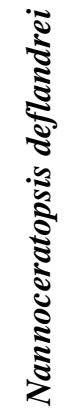 & 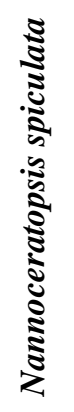 & 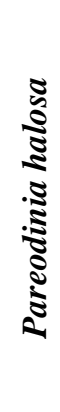 & 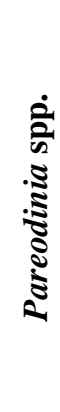 & 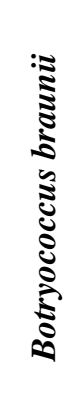 & 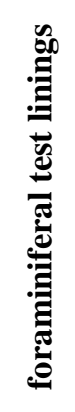 & 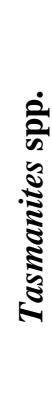 \\
\hline 21 & 18 & 96 & 34 & 4 & $\ldots$ & 2 & $\ldots$ & $\ldots$ & 7 & $\ldots$ \\
\hline 22 & $\ldots$ & 762 & $\ldots$ & $\ldots$ & $\ldots$ & $\ldots$ & $\ldots$ & 1 & $\ldots$ & $\ldots$ \\
\hline 20 & $\ldots$ & 9 & $\ldots$ & $\ldots$ & $\ldots$ & 2 & $\ldots$ & $\ldots$ & $\ldots$ & 1 \\
\hline 28 & $\ldots$ & 148 & 9 & $\ldots$ & $\ldots$ & $\ldots$ & 1 & $\ldots$ & $\ldots$ & $\ldots$ \\
\hline 31 & $\ldots$ & 653 & 34 & $? 1$ & $\ldots$ & 3 & $\ldots$ & 1 & $\ldots$ & $\ldots$ \\
\hline 32 & $\ldots$ & 13 & $\ldots$ & 3 & 2 & $\ldots$ & $\ldots$ & $\ldots$ & $\ldots$ & $\ldots$ \\
\hline 33 & $\ldots$ & 349 & 32 & 1 & $\ldots$ & $\ldots$ & $\ldots$ & $\ldots$ & $\ldots$ & $\ldots$ \\
\hline 35 & $\ldots$ & 392 & 121 & 2 & $\ldots$ & $\ldots$ & $\ldots$ & $\ldots$ & 2 & \\
\hline 34 & $\ldots$ & 21 & 12 & & & 3 & 1 & $\ldots$ & $\ldots$ & \\
\hline
\end{tabular}

Table 2. Distribution of dinoflagellate cysts and other microplankton in the samples studied from the Tusk-1 and Tusk- 2 wells. The numbers in the cells are specimens counted per microscope slide, three dots (...) indicates the absence of the respective taxon/morphotype. 


\begin{tabular}{|c|c|c|c|c|c|c|c|c|c|c|}
\hline \multirow[b]{2}{*}{ 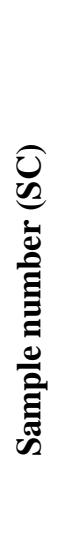 } & \multicolumn{10}{|c|}{ Pollen } \\
\hline & 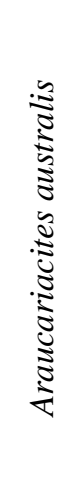 & 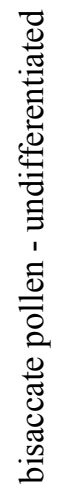 & 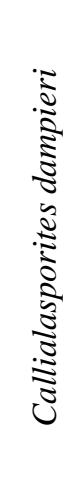 & 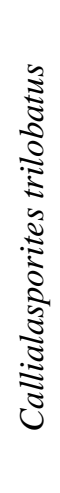 & 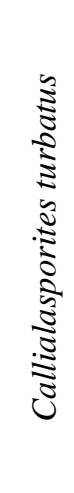 & 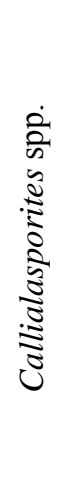 & 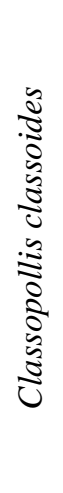 & 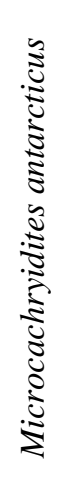 & 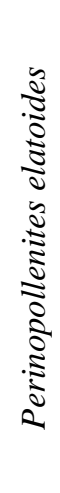 & 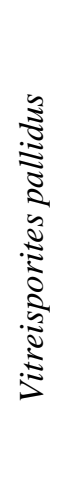 \\
\hline 21 & 8 & 8 & 63 & 3 & 38 & 3 & 39 & $\ldots$ & .. & $\ldots$ \\
\hline 22 & 10 & 1 & 87 & 4 & 109 & $\ldots$ & $\ldots$ & $\ldots$ & $\ldots$ & $\ldots$ \\
\hline 20 & 6 & 41 & 324 & $\ldots$ & 192 & 20 & 31 & 1 & 1 & $\ldots$ \\
\hline 28 & 38 & 3 & 119 & $\ldots$ & 162 & $\ldots$ & $\ldots$ & $\ldots$ & $\ldots$ & $\ldots$ \\
\hline 31 & 164 & 23 & 322 & $\ldots$ & 183 & $\ldots$ & $\ldots$ & $\ldots$ & $\ldots$ & $? 1$ \\
\hline 32 & 42 & 29 & 203 & $\ldots$ & 184 & $\ldots$ & $\ldots$ & $\ldots$ & $\ldots$ & $\ldots$ \\
\hline 33 & 65 & 3 & 161 & $\ldots$ & 96 & $\ldots$ & $\ldots$ & $\ldots$ & 38 & $\ldots$ \\
\hline 35 & 31 & 17 & 547 & $\ldots$ & 271 & & $\ldots$ & $\ldots$ & & $\ldots$ \\
\hline 34 & 7 & 27 & 437 & 24 & 572 & & 3 & & 21 & \\
\hline
\end{tabular}

Table 3. Distribution of gymnosperm pollen in the samples studied from the Tusk-1 and Tusk-2 wells. The numbers in the cells are specimens counted per microscope slide, three dots (...) indicates the absence of the respective taxon/morphotype. 


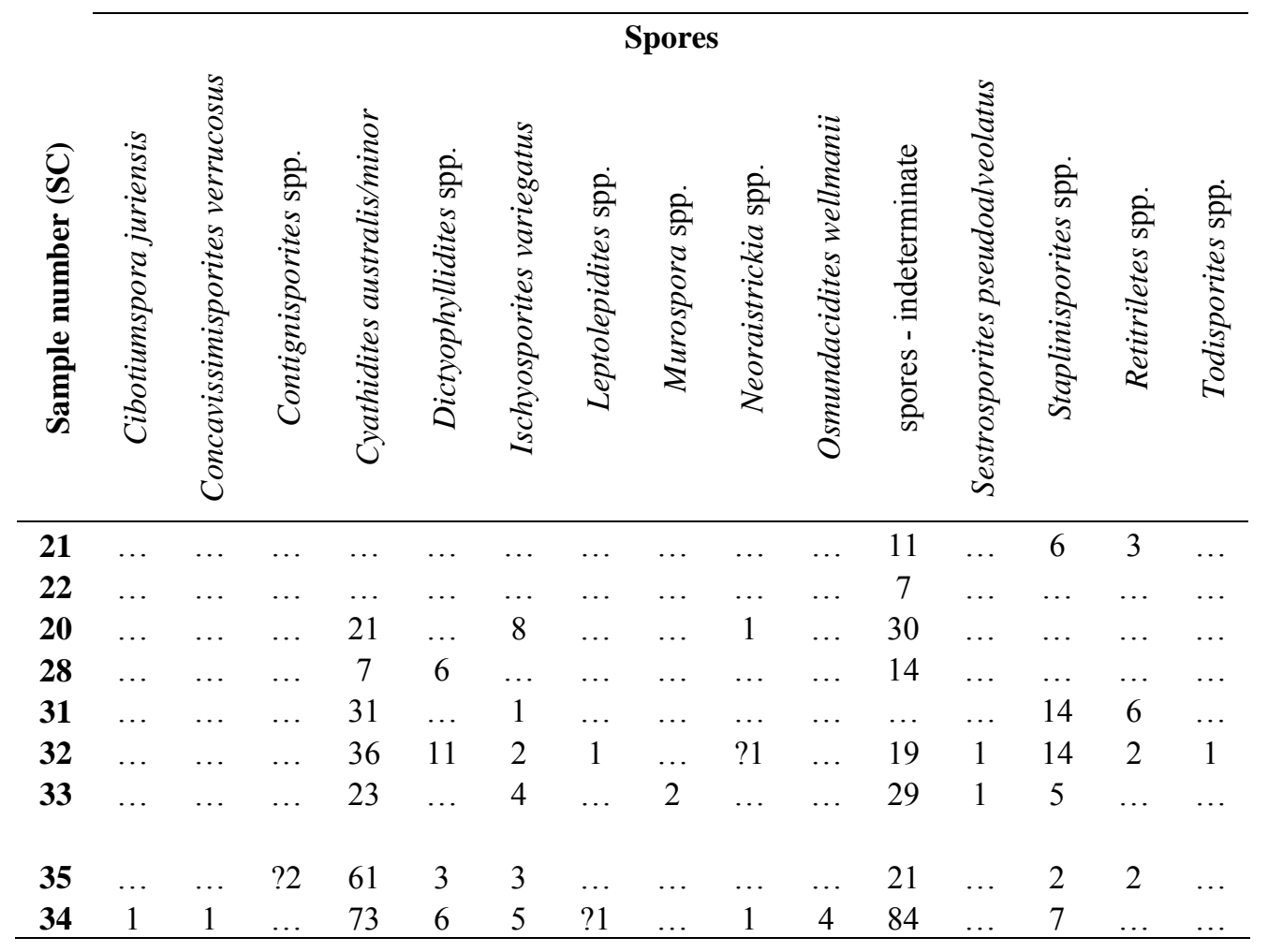

Table 4. Distribution of pteridophyte spores in the samples studied from the Tusk-1 and Tusk-2 wells. The numbers in the cells are specimens counted per microscope slide, three dots (...) indicates the absence of the respective taxon/morphotype. 